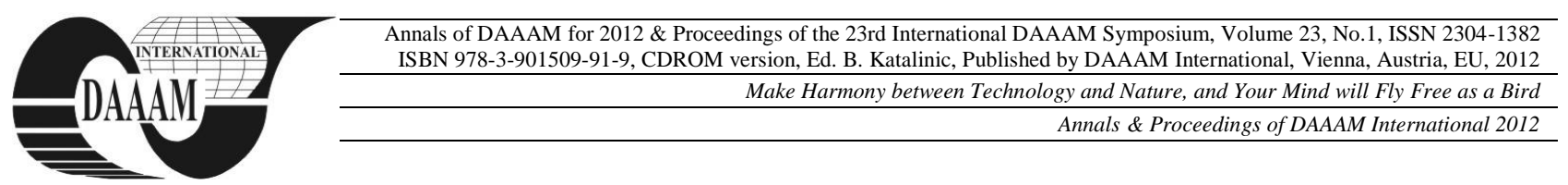

\title{
SERVICE PRICE DETERMINATION AT CROATIAN FACULTIES
}

\author{
DRAZIC LUTILSKY, I[vana] \& ZMUK, B[erislav]
}

\begin{abstract}
Costs are important element in a decision making process by determination or calculation prices and remunerations for provided services or purchased goods from budgetary users. It is important for faculties to use costs when they are determining prices for their services because costs of provided services are partially in some cases charged to students. So the determination of prices is social and, often, political question. The statistical analysis has shown that there are some significant external influences on service price determination, there is no statistical dependence between service costs coverage and way of price service determination, and that the political influence has a lowest impact on service price determination.
\end{abstract}

Keywords: costs, price determination, Croatian faculties, statistical analysis

\section{INTRODUCTION}

Price determination at Faculties mostly depends on some external elements like social criteria and students interest. In Croatia, main source for financing high education is state budget which only partially provides sources for wages, material costs and some level of scientific work. Very high percentages of Croatian faculties are financed out of state budgets in almost from $70 \%$ to $100 \%$. Because of that cost allocation method could be very useful. With those methods they could charge prices of provided services based on occurred costs. Implementing the accrual principle and cost control into the all governmental units, the performance measurements and program efficiency evaluation will be made on actual relevant data. In accordance to that, the decision making process will be based on relevant data.

In the last century a new financial surrounding was defined for high education. Mainly because of decreasing resources from state budget and that fact is encouraging commercial activities like researches financed out of some other source like private business subjects, foundations, international organizations and similar. Higher education costs are increasing with higher rate then the state can assure financial resources from budget and because of that Faculties should find more different sources of financing. Faculties should be competent in governing strategically with their asset and finances, but also human resources especially because teachers are the key to maintain studies and programs of Faculties in future.

Research field for this paper are Faculties and their implementation of cost and managerial accounting into the accounting system. Since, the price determination of studies and financing high education in generally is a very significant and "hot topic" in Croatia these days, it is very important to show with this paper that Faculties don't have relevant information's about occurred costs and internal settlement on which basis they could determined scholarships. With that on mind, the hypotheses were set up:

H1: There is a significant external influence on service price determination.

H2: Costs coverage depends on way of price service determination.

H3: Political influence has the greatest impact on service price determination.

\section{OVERVIEW}

Since the end of the 20th and the beginning of the 21 st century, new public management has been the most emphasized reform in the set of public sector reforms. New public management is the "movement" with the goal of enhancing efficiency in public sector, strengthening responsibilities of government units toward users and buyers of its services, decreasing public expenditures, and management responsibilities' improvement and strengthening [1]. It has been written that the choice of instruments for achieving the above mentioned goals is rather similar and refers to commercializing government operations, and requires possible usage of cost and managerial accounting in public sector. [1].

The change refers to strengthening management responsibilities, the priority of measurement of input being replaced with the measurement and control of the output, improvements in methodology for success measurement, etc. [5]. New public management becomes the area of political interventions inside the executive government [1]. Further, until the scope, framework and content of government activities have not been determined, existing broad institutional rules and organizational routines used by government units for management, operations and supervision, are considered and described as public management.

Contrary to private sector, whose performance is measured by the level of profit made, performance of individual government units and the whole public sector may be measured by level of satisfaction of general and common needs of individuals and the public. Performance has to be measured by segments and by results in each government unit. Also, each program and project has to be measured according to goal fulfillment. For long term sustainability of its activities and programs, public sector has to decrease costs and 
improve quality of its services. Without knowing the structure of each cost and different concepts of their valuation, decreasing costs would be "mission impossible". So, the cost allocation process in public sector is necessary.

Besides the historical role of cost accounting which may be seen as determination of inventories value or other form of assets for financial accounting needs, cost accounting has several basic managerial functions [6]:

- budgeting;

- cost control and cost decreasing;

determination of prices and remunerations;

measurement of performance;

program assessment;

different choices for economic decisions.

Costs information can be used in some specific areas [6] but also for determination of price, fees and remunerations. The determination of prices which government units charge for providing services (e. g. passport issuance, company registration, scholarships) is partly a political question. But the quality evaluation of full costs of a provided service is necessary for comparison and evaluation of different options in business policies. The determination of prices can be necessary because of internal performance evaluation.

It is obvious that accounting goals and tasks have been evolved. In its early phases managerial accounting has been considered as technique for cost allocation on cost objects and it was mainly considered as the "problem of accountants". Today, managerial accounting in public sector is used for presenting the information on costs for the main purpose of fulfilling managerial needs so that such information is used in management processes in public sector. Managerial accounting becomes viewed as a tool for the new public management [6]. Above mentioned areas of managerial accounting appliance are considered as benefits of using managerial accounting. However, managerial accounting is not present enough in practice of most of the countries. The differences in concepts of its use in public sector exist from country to country. It is rare that managerial accounting is being used in government units which render services for free [3].

Insufficient use of managerial accounting in public sector is mainly due to the following:

- Certain services are free to all citizens and providing goods and services is a primary activity of government units;

- Many costs cannot be determined reliably, e.g. costs of natural resources;

- Criteria for assessment of some activities are missing even when costs are known;

- Government programs and projects are decided on political ground, costs are of a secondary importance;

- Budget uses cash accounting; the only and primary interest of the regulator is the control of budgetary resources, not occurred costs.

Cost allocation is a process which is essential for every company, but also for Faculties. The procedure of allocating costs to defined costs objects is one of the most important procedures. This procedure enables the significant information for qualitative business decision process. Cost allocation provides Faculty management with information regarding services profitability evaluation, segment evaluation and profitability evaluation which are needed for both strategic and operating decisions [4].

The basic purpose of cost allocation process is to determine the cost of a service. Besides that basic purpose, cost allocation is used in order to enable the some purposes and to provide information for economic and non economic decisions. Those purposes are: to motivate managers and employees; to justify costs or compute reimbursement; and to measure performance for reporting to external parties (in this case University or Ministry of education) [4]. The first purpose is the most important one, because cost allocation process is mostly implementing for enabling economic decision such as pricing, capacity, forming the service mix, the implementation of new services, the acceptation of certain student needs and etc. Cost allocation can contribute to motivate Faculty management and employees to design services - studies that are simpler to provide. Also, cost allocation can be used to justify costs or compute reimbursement when certain costs are not included in the cost of a study. Finally, cost allocation is necessary for performance measurement for external reporting [4].

Since cost allocation is a difficult and complicated process which is hard to enforce, a certain activities are needed to be provided in order to make the cost allocation process possible. Cost accounting system has to be designed in the way which it enables cost determination and cost classification. While cost determination is a process which is also required for the purpose of external reporting, cost classification is a process which is extremely important for internal management reporting. It is a basic assumption for the enforcement of cost allocation process in order to determine the cost of a particular product and therefore enable product profitability evaluation. Cost classifications directly enable cost allocation. For the cost allocation purpose, costs are needed to be classified according to the following criteria as time period, management function, accounting treatment, traceability to studies, cost behaviour, decision significance and managerial control [2]. It is important to emphasize that the same cost can be included in several or in all cost classifications. But, all cost classifications mentioned above don't have the same significance for particular accounting purposes.

For the purpose of cost allocation, the relevant cost classifications are: a) traceability to studies; b) management function and c) accounting treatment. These cost classifications are needed to be provided by the accounting system of a Faculty in order to enable cost allocation process. The most important cost classification for cost allocation process and evaluation is classification related to accounting treatment. In order to provide the cost allocation process, all costs of a particular accounting period are cost of studies. Generally, studies costs are all costs regarding the providing function of a Faculty. These are providing costs which are directly or indirectly involved in studies. All costs of providing studies at Faculty are indirect costs. Indirect costs, or 
overheads, are those costs which cannot be traced to the particular studies or a research. Because overheads cannot be identified to the particular objects, these costs need to be allocated using appropriate accounting methods. Occurred costs are related to the objects and in that way affect future economic value. Occurred costs become expenses in the same period in which they are incurred and are matched to revenues of the particular accounting period. That way, costs have immediate impact on financial result in the period of their appearance. Those costs include all administrative costs.

\section{EMPIRICAL RESEARCH}

\subsection{Data}

Empirical research was conducted in 64 Croatian Higher Education Institution (further CHEI) through questionnaire in 2006 at the beginning of Bologna process. Head of Accounting Department is a reporting unit while Institutions of higher education are analyzed units. The assumption is that accountants are very familiar with financial results from provided services at their Institution. Overall 25 heads of Accounting Departments have responded to the questionnaire. But, doing the analyses of research results it was obvious that they did not answer on all questions. Therefore, the total number of responses is not equal to 25 on each question.

Within this paper, several questions will be specially emphasized, with the purpose of proving the hypothesis. First raised question would be how price of services are determined. There are 6 categories of services which could be clustered in two groups of services.

The first group of services or comprehensive services related to educational services like: undergraduate study, graduate study and postgraduate study. The second group is consisted of noneduactional services like research, professional and administrative services. The results of a research are shown in Table 1.

\begin{tabular}{|l|c|c|c|}
\hline \multirow{2}{*}{\multicolumn{1}{|c|}{ Services }} & \multicolumn{3}{|c|}{ Way of price service determination } \\
\cline { 2 - 4 } & Internal & External & Combination \\
\hline Undergraduate study & 7 & 7 & 6 \\
\hline Graduate study & 2 & 13 & 8 \\
\hline Postgraduate study & 7 & 3 & 8 \\
\hline Research & 4 & 6 & 9 \\
\hline Proffessional services & 18 & 1 & 3 \\
\hline Administrative services & 12 & 2 & 5 \\
\hline
\end{tabular}

Tab. 1. Determination of service prices

Next question, that was raised, is whether the occurred costs of provided services are covered or not. It can be distinguished two situations. The first is that CHEI with the price of their services covers all occurred costs of provided services. On the other hand, the second situation would be that CHEI do not cover or only partially covers all occurred costs of provided services. The answers are given in a Table 2 .

Another important question from conducted research is what elements are considered in a process of price determination.

\begin{tabular}{|c|c|c|}
\hline \multirow{2}{*}{ Services } & \multicolumn{2}{|c|}{ Coverage of costs } \\
\cline { 2 - 3 } & Yes & No \\
\hline Undergraduate study & 14 & 5 \\
\hline
\end{tabular}

\begin{tabular}{|l|c|c|}
\hline \multirow{2}{*}{\multicolumn{1}{|c|}{ Services }} & \multicolumn{2}{c|}{ Coverage of costs } \\
\cline { 2 - 3 } & Yes & No \\
\hline Graduate study & 10 & 13 \\
\hline Postgraduate study & 14 & 4 \\
\hline Research & 15 & 5 \\
\hline Proffessional services & 21 & 1 \\
\hline Administrative services & 10 & 7 \\
\hline
\end{tabular}

Tab. 2. Cost coverage with the determined price of services

In research 5 elements were used in total. Those elements are: social, political, exclusivity, student's and management's interests. The heads of Accounting Department had to grade from 1 to 5 the impact of those elements on service price determination. Grade 1 means that there is no significant impact and grade 5 means that the element has a very significant impact on service price determination. The results of a research are shown in Table 3.

\begin{tabular}{|l|c|c|c|c|c|}
\hline \multirow{2}{*}{\multicolumn{1}{|c|}{ Element }} & \multicolumn{6}{c|}{$\begin{array}{c}\text { Significance of elements on service } \\
\text { price determination }\end{array}$} \\
\cline { 2 - 6 } & $\mathbf{1}$ & $\mathbf{2}$ & $\mathbf{3}$ & $\mathbf{4}$ & $\mathbf{5}$ \\
\hline Social element & 2 & 3 & 4 & 9 & 2 \\
\hline Political element & 8 & 5 & 4 & 2 & 0 \\
\hline Faculty,,exclusivity“ & 2 & 0 & 5 & 8 & 3 \\
\hline Student's interest & 0 & 0 & 2 & 11 & 8 \\
\hline Management's interest & 3 & 0 & 4 & 9 & 4 \\
\hline
\end{tabular}

Tab. 3. Grading of significance of elements on service price determination

\subsection{Statistical analysis}

In previous research [3] it is estimated that in average CHEI are financed $60.4 \%$ from state budget. Because of that the hypothesis that there is a significant external influence on service price determination was stated. In order to test the hypothesis, the test about a single population proportion was used. In this case it was assumed that in less than $50 \%$ of CHEI are determining prices of services internally. Since it is a lower-tailed test, the assumed thesis will be stated in alternative hypothesis H1. Test was carried out for all 6 services and the results were shown in Table 4.

\begin{tabular}{|l|c|c|c|c|}
\hline \multicolumn{1}{|c|}{ Services } & $\begin{array}{c}\text { Sample } \\
\text { proportion }\end{array}$ & $\begin{array}{c}\text { Stand. } \\
\text { error }\end{array}$ & z-value & p-value \\
\hline $\begin{array}{l}\text { Undergraduate } \\
\text { study }\end{array}$ & 0.350 & 0.1118 & -1.3416 & 0.0899 \\
\hline Graduate study & 0.087 & 0.1043 & -3.9618 & 0.0000 \\
\hline $\begin{array}{l}\text { Postgraduate } \\
\text { study }\end{array}$ & 0.389 & 0.1179 & -0.9428 & 0.1729 \\
\hline Research & 0.211 & 0.1147 & -2.5236 & 0.0058 \\
\hline $\begin{array}{l}\text { Proffessional } \\
\text { services }\end{array}$ & 0.818 & 0.1066 & 2.9848 & 0.9986 \\
\hline $\begin{array}{l}\text { Administrative } \\
\text { services }\end{array}$ & 0.632 & 0.1147 & 1.1471 & 0.8743 \\
\hline
\end{tabular}

determination

Under significance level of $10 \%$ or with $\alpha=0.10$, it was shown that for 3 services it can be rejected assumption that less than $50 \%$ of CHEI are determining prices of services, while for other 3 services this assumption can not be rejected. Precisely, with the significance level it was shown that less than $50 \%$ of CHEI has autonomy in determining prices of following services: undergraduate study, graduate study and research. It is estimated that at least $50 \%$ of CHEI prices of other services are determined autonomously. Based on the conducted test it can be concluded that hypothesis 
about significant external influence could be partially accepted.

For the second hypothesis service costs coverage depends on way of price service determination, it was planned to use Chi-square test but it was shown that the sample was too small and that could distort the assumptions of Chi-square test. Because of that Fisher's exact test was used. This test in its null hypothesis assumed that the relative proportions of one variable are independent of the second variable. In this case one variable will be the way in determining service price whether is internal or external, while the other variable will be cost coverage of the determined service price. The test was performed for each of 6 services and the results are shown in Table 5.

\begin{tabular}{|c|c|c|c|c|}
\hline \multirow[b]{2}{*}{ Services } & \multirow[b]{2}{*}{$\begin{array}{c}\text { Variable } \\
\text { cost } \\
\text { coverage }\end{array}$} & \multicolumn{2}{|c|}{$\begin{array}{c}\text { Variable service price } \\
\text { determination }\end{array}$} & \multirow{2}{*}{$\begin{array}{c}p \text {-value } \\
\text { (two- } \\
\text { tailed) }\end{array}$} \\
\hline & & Internally & Externally & \\
\hline \multirow{2}{*}{$\begin{array}{l}\text { Undergraduate } \\
\text { study }\end{array}$} & Yes & 7 & 6 & \multirow{2}{*}{0.1029} \\
\hline & No & 0 & 4 & \\
\hline \multirow{2}{*}{ Graduate study } & Yes & 3 & 4 & \multirow{2}{*}{1.0000} \\
\hline & No & 3 & 6 & \\
\hline \multirow{2}{*}{$\begin{array}{l}\text { Postgraduate } \\
\text { study }\end{array}$} & Yes & 5 & 7 & \multirow{2}{*}{1.0000} \\
\hline & No & 2 & 2 & \\
\hline \multirow{2}{*}{ Research } & Yes & 2 & 11 & \multirow{2}{*}{1.0000} \\
\hline & No & 1 & 4 & \\
\hline \multirow{2}{*}{$\begin{array}{l}\text { Proffessional } \\
\text { services }\end{array}$} & Yes & 15 & 4 & \multirow{2}{*}{1.0000} \\
\hline & No & 1 & 0 & \\
\hline \multirow{2}{*}{$\begin{array}{l}\text { Administrative } \\
\text { services }\end{array}$} & Yes & 6 & 3 & \multirow{2}{*}{0.3147} \\
\hline & No & 2 & 4 & \\
\hline
\end{tabular}

Tab. 5. Independence of variables determination of service prices and cost coverage with the determined price

Results of test have shown that for $\alpha=0.10$ there is no statistical dependency between variables for all 6 services. It could be concluded that the way of determining service prices, internally or externally, does not influence on coverage of costs from provided service prices. It was shown that external influence on service price determination does not directly influence on that whether the cost will be covered with the determined price or not.

Previously it was shown that the way for service price determination does not influence on coverage of costs of provided services. That is the reason why it was important to try to discover what elements influence on service price determination. In total 5 elements were defined and their impact on service price determination was tested with Wilcoxon signed rank test. The results of performed tests are shown in Table 6.

\begin{tabular}{|l|c|c|c|}
\hline \multirow{2}{*}{\multicolumn{1}{|c|}{ Element }} & \multicolumn{2}{|c|}{ Hypothesis } & \multirow{2}{*}{ p-value } \\
\cline { 2 - 3 } & $\boldsymbol{H}_{\boldsymbol{0}}$ & $\boldsymbol{H}_{\boldsymbol{I}}$ & \\
\hline Social element & $\eta \leq 3$ & $\eta>3$ & 0.308 \\
\hline Political element & $\eta \leq 2$ & $\eta>2$ & 0.845 \\
\hline Faculty,,exclusivity“ & $\eta \leq 3$ & $\eta>3$ & 0.197 \\
\hline Student's interest & $\eta \leq 4$ & $\eta>4$ & 0.155 \\
\hline Management's interest & $\eta \leq 4$ & $\eta>4$ & 0.477 \\
\hline
\end{tabular}

Tab. 6. Impact of elements on service price determination

In all test it was shown that for $\alpha=0.10$ the null hypothesis could not be rejected for all 5 observed elements. But it can be observed that different values of assumed median were used. The test for political element, which is the most important element according the third hypothesis of this paper, has shown that on $50 \%$ faculties impact of politics is insignificant or with low significance. Other elements have shown higher significance on service price determination. On this basis, the third hypothesis Political influence has the greatest impact on service price determination, can be rejected.

\section{CONCLUSION}

First hypothesis how there is a significant external influence on service price determination was only partially confirmed. The second one that costs coverage depends on way of price service determination was rejected under conducted test and the third hypothesis that political influence has the greatest impact on service price determination was also rejected. The authors belive, that it is important for faculties to use costs when they are determining prices for their studies. It is necessary because costs of provided services were partially charged to students. Determination of cost for provided services is also necessary for settlement of costs and internal reporting. That is useful primary to internal users or faculty management in decision making process for financial and non financial decisions. In Republic Croatia practice for price determinations of provided services is usually social question rather than economical one. Since this research was done in 2006 for our future research we are planning to send the same questionnaire to the tested units and to see whether the situation has changed.

\section{REFERENCES}

[1] Barzelay, M. (2001). The New Public Management, Improving Research and Policy Dialogue, University of California Press, ISBN: 978-0520224438, California

[2] Cherington, J. O.; Hubbard, E. D. \& Luthy, D. H. (1985). Cost and Managerial Accounting, WCB Publishers, ISBN: 9780697082312, Dubuque, Iowa

[3] Drazic Lutilsky, I. (2011). Uporaba informacija o troškovima na visokoškolskim ustanovama u Republici Hrvatskoj (Usage of cost information at Croatian high education institutions) . Zbornik Ekonomskog fakulteta u Zagrebu, Vol. 9., No. 2, 209-228, ISSN: 1333-8900

[4] Horngren, C. T.; Datar, S. M. \& Foster, G. (2003). Cost Accounting - A Managerial Emphasis, 11th ed., Prentice Hall, ISBN: 978-0130996190, New Jersey

[5] Hughes, O. \& O`Nill, D. (2002). The limits of new public management: Reflection on the Kennett «revolution» in Victoria, Available from: http://www.inpuma.research/papers/sydney/ hughesoneill.html, Accessed: 2012-04-30

[6] IFAC-PSC (2000). Perspectives on Cost Accounting for Government, Study 12 